\title{
Article \\ Dietary Habits of Female University Students in Eastern Slovakia in the Context of Sports Activity
}

\author{
Alena Buková ${ }^{1}$, Klaudia Zusková ${ }^{1}$, Ladislav Kručanica ${ }^{1} \mathbb{1}$, Zuzana Küchelová ${ }^{1}$, Lenka Urbanská ${ }^{2}$ \\ and Richard Melichar ${ }^{1, *}$ \\ 1 Institute of Physical Education and Sport, Pavol Jozef Šafárik University in Košice, 04011 Košice, Slovakia; \\ alena.bukova@upjs.sk (A.B.); klaudia.zuskova@upjs.sk (K.Z.); ladislav.krucanica@upjs.sk (L.K.); \\ zuzana.kuchelova@upjs.sk (Z.K.) \\ 2 Faculty of Medicine, Pavol Jozef Šafárik University in Košice, 04011 Košice, Slovakia; lenka.urbanska@upjs.sk \\ * Correspondence: richard.melichar@upjs.sk
}

check for

updates

Citation: Buková, A.; Zusková, K.; Kručanica, L.; Küchelová, Z.; Urbanská, L.; Melichar, R. Dietary Habits of Female University Students in Eastern Slovakia in the Context of Sports Activity. Appl. Sci. 2021, 11, 6402. https://doi.org/10.3390/ app11146402

Academic Editor:

Wojciech Kolanowski

Received: 15 June 2021

Accepted: 8 July 2021

Published: 11 July 2021

Publisher's Note: MDPI stays neutral with regard to jurisdictional claims in published maps and institutional affiliations.

Copyright: (c) 2021 by the authors. Licensee MDPI, Basel, Switzerland. This article is an open access article distributed under the terms and conditions of the Creative Commons Attribution (CC BY) license (https:/ / creativecommons.org/licenses/by/ $4.0 /)$.

\begin{abstract}
Background: The aim of the research was to expand the current knowledge about the diets of female university students in relation to the frequency of their sports activity (SA). We were specifically interested in the eating frequency, the distribution of the amount of food during the day, including breakfast in the diet, and the timing of dinner before bedtime. (2) Methods: The sample in this cross-sectional research consisted of 1055 female freshmen university students from the two universities in eastern Slovakia. Data were obtained through a set of selected questions from a questionnaire battery. (3) Results: We found a significant rank-order correlation between the frequency of meals during the day and the level of SA, as well as between the consumption of breakfast and SA. Furthermore, we found a significant indirect dependence on the distribution of meals during the day and SA. The results indicate a better dietary pattern of the more active female students in terms of the frequency of meals. (4) Conclusions: "The healthy behaviour", which includes proper diet and regular SA, was monitored in the cross-sectional research we conducted, the results of which consistently point to opportunities for further improvement. There is a need for universities to develop professionally targeted programmes that will enable novice students to modify their health behaviours during their studies.
\end{abstract}

Keywords: female university students; sports activity; frequency of meals; breakfast; dinner

\section{Introduction}

Rational nutrition and proper diet are the main pillars of a healthy lifestyle and, together with sports activity (SA), they have a significant impact on the health of adolescents [1]. Rational nutrition affects the physical and mental performance of a person. A proper daily dietary regimen and rhythm also has a preventive effect against some diseases [2]. Adequate food choices and good eating habits are essential for maintaining a healthy lifestyle and for the health of the youth [3-5]. However, the nutritional habits of university students pose a significant threat to their lifestyle. University is considered a high-risk-factor environment in terms of urging undergraduates to eat disorderly [6,7]. The nutritional risks specific to university students are alarming to the extent that unhealthy eating habits constitute one of the six biggest health risks for the students [8]. The transition to an independent way of life by entering university can be very stressful and can affect food choices and dietary patterns [9,10], and this is particularly the case if the university students are living away from home [11]. Physiological and psychological factors in dormitories can lead to disordered eating, including swapping roles and duties, lack of exercise, self-service canteens, and the availability of simple foods [12,13]. In addition, due to the lack of time associated with the amount of studying, many students are forced to eat in a hurry and therefore largely prefer the consumption of fast food with high calorie content and low nutritional value $[13,14]$. Adolescent eating habits are characterised by high consumption 
of sweets and sweetened soft drinks, skipping breakfast, and low consumption of fruits and vegetables [14,15]. According to several authors [7,14-17], breakfast omissions, fast food, sweet drinks, and an unbalanced diet are the main food patterns in this population group.

Several experts in Slovakia [18-21], Poland [22,23], Serbia [24], Spain [15], and Norway [25], as well as in distant countries such as Colombia [26], Turkey [27], Australia [28], the USA [29], and China [16,17,30], have pointed out the inappropriate eating habits and poor dietary regime of university students. Nonetheless, irregular eating habits and negative views of body weight have their roots even before entering university $[12,31,32]$.

There are many factors that influence students' health behaviour in relation to diet, but to change their eating habits, it is necessary to understand some basic requirements in relation to nutrition, whether it is education in making healthier food choices or their ability to apply this knowledge in practice [33].

The studies regarding the impact of nutritional education on the dietary habits of university students are inconsistent. Several studies have disclosed that nutritional education can change students' eating habits and food choices [10,34], while others have not reported a significant correlation between these variables [35]. It is usually difficult to distinguish between the effect of diet and the effect of SA. According to Hendl and Dobrý [36], it is typical for physically active individuals to eat a healthier diet. According to the authors, SA is also the most important factor for eliminating some of the negative effects of poor nutrition.

In terms of gender differences, there is generally a higher presumption of healthy eating and healthy habits in women, with men showing less interest in obtaining nutrition and health improvement counselling [37]. In addition, female students are more concerned about changing their eating habits than males. On the other hand, women's negative perception of their own figures, additionally influenced by their environment and TV commercials, can lead to eating disorders, poor eating habits, various diet plans, dietary adjustments, or even skipping meals. For this reason, our sample consisted particularly of female university students, anticipating significant differences between physically active and inactive students. The weekly frequency of sports activity was decisive in this work in order to emphasise the importance and relevance of regularly performed sports activities in relation to the selected lifestyle factors and health status of university freshmen.

The aim of this research was to identify the eating habits of female university students in eastern Slovakia and to analyse this information in reflection of their weekly sports activity.

\section{Materials and Methods}

\subsection{Sample and Procedure}

We addressed 1175 female freshmen university students from the two largest universities in eastern Slovakia, namely, 5 faculties at Pavol Jozef Šafárik University in Košice (UPJك̌; $n=727 ; 68.9 \%$ ) and 8 faculties at the Technical University in Košice (TUKE; $n=328$; $31.1 \%), 81$ of whom declined to participate in the research. We also excluded a further 16 students for not meeting one or more of the essential criteria listed below. We excluded 23 questionnaires due to incorrect or incomplete completion. The criteria for participating in this research were met by 1055 freshmen university students. The average age of the participants was 19.4 years. Basic anthropometric characteristics of students participating in the study are presented in Table 1, and the distribution of count according to the type of housing and place of current residence is presented in Table 2. Data on the frequency of sports activities during the last six months were obtained by selected questions from a questionnaire battery, compiled for the needs of a broader study conducted previously. Data on dietary habits of female students were collected using particular items from the Eating Habits Questionnaire, developed and validated by Philpsen [38]. 
Table 1. Basic anthropometric indicators of respondents.

\begin{tabular}{ccccc}
\hline & \multicolumn{2}{c}{ UPJŠ } & \multicolumn{2}{c}{ TUKE } \\
\cline { 2 - 5 } & $\mathbf{n}$ & SD & $\mathbf{n}$ & SD \\
\hline age & 19.22 & 2.17 & 19.55 & 1.16 \\
BMI & 22.14 & 8.9 & 21.92 & 3.74 \\
WHR & 0.76 & 0.09 & 0.77 & 0.09 \\
\% fat & 29.32 & 7.98 & 30.4 & 7.2 \\
\hline
\end{tabular}

UPJŠ—Pavol Jozef Šafárik University, TUKE-Technical University in Košice.

Table 2. Place of permanent residence and current residence of respondents.

\begin{tabular}{ccccccc}
\hline \multirow{2}{*}{$\boldsymbol{n}=\mathbf{1 0 5 5}$} & \multicolumn{2}{c}{ UPJŠ } & \multicolumn{2}{c}{ TUKE } & \multicolumn{2}{c}{ Total } \\
\cline { 2 - 7 } & $\mathbf{n}$ & $\mathbf{\%}$ & $\mathbf{n}$ & $\mathbf{\%}$ & $\mathbf{n}$ & $\mathbf{\%}$ \\
\hline urban & 449 & $61.7 \%$ & 175 & $53 \%$ & 624 & $59 \%$ \\
rural & 278 & $38.3 \%$ & 153 & $47 \%$ & 431 & $41 \%$ \\
\hline at home & 337 & $46.6 \%$ & 168 & $51.2 \%$ & 505 & $48.1 \%$ \\
dormitory & 317 & $43.3 \%$ & 138 & $42.1 \%$ & 455 & $43 \%$ \\
sublease & 73 & $9.9 \%$ & 22 & $6.7 \%$ & 95 & $8.9 \%$ \\
total & 727 & $100 \%$ & 328 & $100 \%$ & 1055 & $100 \%$ \\
\hline
\end{tabular}

UPJŠ_Pavol Jozef Šafárik University, TUKE-Technical University in Košice.

The questionnaire included written information about its scientific significance, which was also presented to the probands verbally, and information about the confidentiality of the survey responses.

For the purposes of this study, we used the following questions from the questionnaire battery:

- Have you been regularly exercising or playing sports in the past six months?

- How many times a day do you eat?

- Please indicate the typical part of the day with your highest food intake-options listed.

- Do you have breakfast every day?

- If you have dinner, how long before bedtime?-time interval values listed.

All variables were determined in relation to the duration amount of weekly sporting activity.

The participants were verbally informed about the main aim of the study, the procedures, risks and benefits, confidentiality, and the voluntary nature of their participation, and were given the opportunity to ask questions. Prior to their enrolment, written informed consent was obtained from all the probands in accordance with the Declaration of Helsinki [39].

\subsection{Sample Size}

In the given year, 113,298 students studied at the university in Slovakia it the first degree of study. We calculated minimum sample size according to the estimation given in Daniel [40], where $n=\mathrm{Z}^{2} \mathrm{P}(1-p) / \mathrm{d}^{2}(\mathrm{Z}=2.576$ for $99 \%$ level of confidence; $p=0.5$ for expected sample proportion of $50 \% ; d=0.05$ for the $5 \%$ margin of error). Based on this calculation, the minimum number was set at $n=660$ women. We set a higher number of $n=1247$ because we anticipated a 30-50\% loss. Therefore, our sample of 1055 respondents is representative considering the number of university students in Slovakia.

\subsection{Inclusion and Exclusion Criteria}

Inclusion criteria were the following: 
- Age-18-23 years;

- Gender-female;

- Student of the first year in the first degree of study;

- Slovak nationality;

Exclusion criteria were the following:

- $\quad$ Repeating the first year of study;

- Student of the external form of study;

- Student of another university, except for the monitored universities;

- Mental and physical disorders/impairment;

- Further health problems that hinder sports activities.

\subsection{Statistical Analysis}

In terms of statistical interference, our research focused on the following:

- The demonstration of statistical significance of differences between the frequencies;

- The examination of interrelationships and dependencies between the observed attributes.

The relationships and dependencies between the variables were evaluated using the statistical methods of the " $\chi^{2}$-chi-squared test of independence" and "binary logistic regression". We used adjusted residuals to measure the significance of the differences between the observed and expected values. If the values of the statistics exceeded the critical values, each cell was assigned a plus (+) or a minus (-) symbol, depending on how significant the deviation was and whether the difference between the sample and the expected frequency values was positive or negative. The "+" and "-" symbols were assigned according to three levels of significance. In case of rejecting the hypothesis of independence, Cramer's V was used to measure the tightness of dependence between two qualitative attributes, and Kendall's tau-b $\left(\tau_{b}\right)$ rank correlation coefficient was used to measure the ordinal association between the measured quantities.

The statistical analysis was performed using IBM SPSS Statistics v24 statistical software, while the statistical significance of the obtained results was determined at the significance levels of $\alpha=0.05$ and 0.01 .

\section{Results}

\subsection{Weekly Frequency of $S A$}

Descriptive statistics of the SA at the two largest universities in Slovakia showed that $68 \%$ of the female students were inactive, meaning that they had performed irregular or no SA in the last six months (Table 3). For the purposes of this study, SA was recognised as a deliberate sports activity that was performed for at least $10 \mathrm{~min}$. Walking as a part of commuting was not considered SA. Table 4 presents the result of the chi-squared test between groups of SA participation.

Table 3. SA of university students in the last six months.

\begin{tabular}{ccc}
\hline & $\mathbf{n}$ & \% \\
\hline SA-0 = no SA & 104 & 9.9 \\
SA-N = irregular SA & 613 & 58.1 \\
$1 \mathrm{x}=$ SA performed once a week & 111 & 10.5 \\
$2 \mathrm{x}=$ SA performed 2 times a week & 109 & 10.3 \\
$3 \mathrm{x}=$ SA performed 3 times a week & 118 & 11.2 \\
Total & 1055 & $100 \%$ \\
\hline
\end{tabular}

$\mathrm{N}-$ absolute count, \%-relative count. 
Table 4. Chi-squared test correlation between groups of SA participation.

\begin{tabular}{cccccccccc}
\hline \multirow{2}{*}{ SA } & \multicolumn{2}{c}{ SA-0 } & \multicolumn{2}{c}{ SA-N } & & $\mathbf{1 x}$ & \multicolumn{2}{c}{$\mathbf{2 x}$} \\
\cline { 2 - 9 } & $\chi^{2}$ & $p$ & $\chi^{2}$ & $p$ & $\chi^{2}$ & $p$ & $\chi^{2}$ \\
SA-N & 361.34 & $* *$ & & & & & \\
1x weekly & 0.228 & 0.633 & 348.072 & $* *$ & & & \\
2x weekly & 0.117 & 0.732 & 351.823 & $* *$ & 0.18 & 0.893 & 0.357 & 0.550 \\
3x weekly & 0.883 & 0.347 & 335.192 & $* *$ & 0.214 & 0.644 & 0 \\
\hline
\end{tabular}

$\mathrm{N}$-absolute count, $\%$-relative count ${ }^{*}$ significancy at $p<0.05 ;{ }^{* *}$ - significant at $p<0.01 \chi^{2}$ —chi-squared test; $p$-probability.

\subsection{Frequency of Meals}

The daily eating frequency of freshmen female students was examined by the number of meals consumed during the day. The categories of the variable "eating frequency" were pooled since the conditions required to use the chi-squared test were not met (Table 5). The differences between the individual pooled categories of eating frequency were substantial and statistically significant. An eating frequency of 3-4 times a day was preferred in all subgroups of weekly SA frequency. The second most common frequency in the group of inactive students was eating 1-2 times a day, and it was 5-6 times a day in the physically active students, where a statistically positive relationship with a low correlation was found $\left(\chi^{2}=21.36, \mathrm{df}=8, p<0.05 ; \tau \mathrm{b}=0.115, p<0.01\right)$. Lower counts against the expected values occurred in the eating frequency of 3-4 times a day, in the group exercising 3 and more times a week, and in the eating frequency of 5-6 times a day in the group of inactive or irregularly active students. The most common eating frequency in all subgroups was 3-4 times a day. We recorded an increased number of students who were eating 5-6 times a day with an increased frequency of SA. Based on the above results, we can confirm that those female students who exercised regularly, even once or more times a week, tended to eat more often (5-6 times a day), compared to the students who did not exercise at all or only irregularly. We also found a significant difference between the eating frequency of 5-6 times a day in the group of students that exercised 3 and more times a week, compared to the inactive students $(p<0.05)$ and the irregularly exercising students $(p<0.05)$. Our assumption about better eating habits in the context of a higher frequency of eating and a higher weekly frequency of SA was therefore confirmed.

In all groups, in relation to SA, the largest amount of food was consumed for lunch, or after lunch (Table 5). There was a statistically significant relationship between the amount of food consumed during the day and the weekly frequency of SA $\left(\chi^{2}=54.928, \mathrm{df}=20\right.$, $p<0.01$; CramerV $=0.114 ; p<0.01$ ). In all the subgroups of SA, the highest percentage of respondents consumed the largest amount of food for lunch. As the frequency of SA increased, the number of female students who consumed the largest amount of food in the morning or for snacks increased slightly, and the number of those who consumed the most food in the afternoon and evening declined. Moreover, we found statistically significant differences in the morning food consumption between the group of irregularly exercising students and the group of students exercising 3 or more times a week $(p<0.05)$. In the case of eating food up until noon, there were significant differences between the groups of inactive $(p<0.05)$ and irregularly exercising students $(p<0.01)$, in favour of the group of students exercising 3 times or more in a week. In the group with the highest food intake in the afternoon, we found a significant difference between the group with irregular SA and the students who performed SA 3 or more times a week $(p<0.05)$.

In all the subgroups of SA, there was a predominance of female students who reported eating breakfast regularly or most of the time. For the correct use of the chi-squared independence test, we also pooled some of the variables in this item (Table 6). We found a statistically significant relationship between the variables $\left(\chi^{2}=17.278, \mathrm{df}=4, p<0.01\right.$; CramerV $=0.128 ; p<0.01)$. Within the variable "eating breakfast as part of the daily regime" in the subgroups of SA, we found that with a higher frequency of doing sports, the number of female students who ate breakfast regularly or mostly regularly increased. We 
also found significant differences between the inactive group and the group that exercised 2 times a week $(p<0.05)$ and 3 or more times a week $(p<0.01)$.

Table 5. Relation between daily eating frequency, meal distribution, and frequency of SA.

\begin{tabular}{|c|c|c|c|c|c|c|}
\hline & \multicolumn{6}{|c|}{ Weekly Frequency of SA (\%) } \\
\hline & SA-0 & SA-N & $1 x$ & $2 x$ & $3 x$ & $\Sigma$ \\
\hline \multicolumn{7}{|c|}{ Daily eating frequency } \\
\hline $1-2 x /$ day & 1.5 & 4.5 & 0.6 & 0.8 & 0.8 & 8 \\
\hline $3-4 x /$ day & 7 & 42.5 & 7.3 & 6.9 & 6.8 & 70.7 \\
\hline $5-6 x /$ day & 1.3 & 11.1 & 2.6 & 2.6 & 3.6 & 21.3 \\
\hline Total & 9.8 & 58.1 & 10.5 & 10.3 & 11.2 & 100 \\
\hline $1-2 x /$ day & ++ & o & $\mathrm{o}$ & $\mathrm{o}$ & $\mathrm{o}$ & \\
\hline $3-4 x /$ day & $\mathrm{o}$ & + & $\mathrm{o}$ & $\mathrm{o}$ & - & \\
\hline $5-6 x /$ day & - & - & $\mathrm{o}$ & o & ++ & \\
\hline \multicolumn{7}{|c|}{ Meal distribution during the day } \\
\hline morning & 0.1 & 1 & 0.4 & 0.5 & 0.8 & 2.8 \\
\hline before midday & 0.3 & 2.8 & 0.9 & 0.9 & 1.5 & 6.3 \\
\hline midday & 4.9 & 28 & 4.9 & 4.9 & 5.4 & 48 \\
\hline afternoon & 2.9 & 18.7 & 3.2 & 2.8 & 1.9 & 29.5 \\
\hline evening & 1.4 & 5.7 & 0.7 & 0.6 & 0.5 & 8.8 \\
\hline balanced distribution & 0.3 & 2 & 0.5 & 0.9 & 1 & 4.6 \\
\hline Total & 9.9 & 58.1 & 10.5 & 10.3 & 11.2 & 100 \\
\hline morning & $\mathrm{o}$ & - & $\mathrm{o}$ & o & ++ & \\
\hline before midday & $\mathrm{o}$ & - & $\mathrm{o}$ & $\mathrm{o}$ & +++ & \\
\hline midday & $\mathrm{o}$ & o & $\mathrm{o}$ & $\mathrm{o}$ & $\mathrm{o}$ & \\
\hline afternoon & $\mathrm{o}$ & + & $\mathrm{o}$ & $\mathrm{o}$ & -- & \\
\hline evening & + & $\mathrm{o}$ & $\mathrm{o}$ & $\mathrm{o}$ & $\mathrm{O}$ & \\
\hline balanced distribution & $\mathrm{o}$ & - & $\mathrm{o}$ & $\mathrm{o}$ & + & \\
\hline
\end{tabular}

Table 6. Relation between consumption of breakfast in the daily regime, dinner time, and frequency of SA.

\begin{tabular}{|c|c|c|c|c|c|c|}
\hline & \multicolumn{6}{|c|}{ Weekly Frequency of SA (\%) } \\
\hline & SA-0 & SA-N & $1 x$ & $2 x$ & $3 x$ & $\Sigma$ \\
\hline \multicolumn{7}{|c|}{ Breakfast in daily regime } \\
\hline no, rarely & 3.9 & 17.1 & 2.5 & 2 & 2.1 & 27.4 \\
\hline yes, mostly & 6 & 41 & 8 & 8.3 & 9.1 & 72.4 \\
\hline Total & 9.9 & 58.1 & 10.5 & 10.3 & 11.2 & 100 \\
\hline no, rarely & ++ & $\mathrm{o}$ & $\mathrm{o}$ & - & - & \\
\hline yes, mostly & -- & o & $\mathrm{o}$ & + & + & \\
\hline \multicolumn{7}{|c|}{ Dinner time before sleep } \\
\hline no dinner & 0.5 & 1.3 & 0.4 & 0.2 & 0.6 & 3 \\
\hline $1-2 \mathrm{~h}$ & 4.4 & 22.6 & 3.7 & 3.8 & 4.1 & 38.6 \\
\hline $3-4 \mathrm{~h}$ & 5 & 34.1 & 6.4 & 6.3 & 6.6 & 58.4 \\
\hline Total & 9.9 & 58.1 & 10.5 & 10.3 & 11.2 & 100 \\
\hline no dinner & $\mathrm{o}$ & $\mathrm{o}$ & $\mathrm{o}$ & $\mathrm{o}$ & $\mathrm{o}$ & \\
\hline $1-2 \mathrm{~h}$ & o & o & $\mathrm{o}$ & $\mathrm{o}$ & $\mathrm{o}$ & \\
\hline $3-4 \mathrm{~h}$ & o & o & o & o & $\mathrm{o}$ & \\
\hline
\end{tabular}

In addition, we analysed the correlations between the students' timing of dinner before bedtime and the frequency of SA in a week. In order to utilise the chi-squared independence test, we again had to pool several items. The differences were not significant and showed that the correlation was low and insignificant $\left(\chi^{2}=6.529, \mathrm{df}=8, p>0.05 ; \mathrm{tb}=0.28 ; p=0.326\right)$. In this variable, the correlation with the frequency of SA was manifested the least. 


\section{Discussion}

The aforementioned findings regarding the low representation of SA in the lifestyle of female university students at two major universities in eastern Slovakia correspond with several studies that point to the insufficient SA of university students across Europe [41-45]. The results of this study seem more optimistic when compared to the 2018 Eurobarometer on adult sport and physical activity, which revealed that up to $49 \%$ of Slovaks and $46 \%$ of Europeans do not participate in sports and 23\% exercise only occasionally (EU 14\%); [46]. However, our study differs from other similar studies in terms of the research tools used, as well as the evaluated parameters and methodology. Therefore, the limitations of this study regarding the comparison of the results need to be taken into account.

At first glance, worse results for SA participation than in our study were observed in students from Germany [47], Czech Republic [48], Romania [49], and Canada [50]. On the contrary, a lower percentage of inactive female students was found in Poland [22], as well as in other studies in the Czech Republic [51] and Hungary [52]. The lower SA of university students can be explained by time constraints, among other factors, as was found in Saudi Arabia [53], Delhi [23], Poland [41,54], Czech Republic [55], and Slovakia [56-58]. However, these time constraints are not necessarily the result of an excessive workload required by universities. They can also be caused by the students' part-time jobs to pay for their study expenses [54]. Awadalla et al. [53] also found some students who reported personal factors such as lack of motivation to participate in SA, weak or no information about the benefits of SA, or lack of sports facilities in their residential area. For a substantial part of university students, the insufficient SA regime is not the result of physical disability but rather indolence and a lack of relevant information [56,59].

In terms of rational nutrition and the prevention of fat metabolism disorders, some authors recommend dividing the daily energy intake into at least five meals $[15,60,61]$. It has been hypothesised that eating small, frequent meals enhances fat loss and helps to achieve better weight maintenance. A number of observational studies lend support to this hypothesis, with an inverse relationship noted between the frequency of eating and adiposity [62]. The authors evaluated the effects of differing meal frequencies on body composition by conducting a meta-analysis. The primary novel and important findings of the analysis are that increased feeding frequency appeared to be positively associated with reductions in fat mass and body fat percentage as well as an increase in fat-free mass. However, sensitivity analysis of the data showed that the positive findings were largely the product of a single study, casting doubt as to whether more frequent meals confer beneficial effects on body composition. These results have important implications with respect to the popular suggestion that eating small, frequent meals is the preferred method for optimising weight management in the general population.

Frequent meals and a short time between meals accelerate metabolism during the day, with the exception of time spent sleeping [63]. Thus, those who eat smaller portions but more often during the day may have a metabolic advantage over those who eat less frequently but larger portions [61]. Consuming a large number of calories in a single serving will increase the absorption of nutrients into the blood, including glucose. Its higher level will cause the secretion of insulin, which causes adipose tissue to also become more sensitive to insulin at higher doses. Therefore, it is necessary to maintain an approximately constant blood glucose level [64]. Such condition can only be maintained by eating regularly, with the breaks between meals being not too long. However, the evidence to support this theory is rather inconclusive. Consuming more calories in a single meal may in fact lead to increased obesity due to increased post-meal synthesis and fat storage, which negatively affects the amount of body fat [61]. The above recommendation-eating meals 5-6 times a day-is followed by more than a fifth of respondents, while with an increasing frequency of SA during the week, the number of female students who eat this way increases. Less than $10 \%$ of female students report eating 1-2 times a day. In this context, such a low frequency of food intake may not be perceived as unfavourable to their health. Recently, some studies have examined the benefits of skipping certain foods, called "intermittent fasting (IF)" [65]. 
IF involves restricting the daily intake of food for the period of 6-8 h, whilst the person consumes only certain foods in limited quantities during the rest of the day. When IF is combined with exercise on an empty stomach, the positive benefits to the body will intensify [66]. From our experience in creating and implementing exercise programmes for women of all ages, we can argue that female students will omit meals rather than implement a weight loss strategy but many times without controlling the nutritional values of their meals. In general, women are more likely to maintain their energy balance, but they also tend to overestimate their body weight and often perceive their bodies incorrectly. These results were also obtained by several authors [28,67-70].

As in other areas concerning lifestyle, there is no universal nutrition consensus in terms of the effects of eating frequency on the human body and health indicators. Eating is a category of behaviour that, to a lesser extent than alcohol consumption, smoking, or SA, depends on one's personal choices and decisions [23]. According to the authors, eating habits are formed by many factors influenced by the place of residence during the study, daily programme, current budget, and the use of university canteen [69]. The diet itself is influenced by many factors-different ways of eating, the type of food, and the actual frequency of meals, including breaks between meals. All of this may lead to different classifications and may affect the findings of the study. Nonetheless, our results showed that a higher frequency of SA is positively related to a higher daily frequency of meals, which may be important in determining or shaping the habits of university students.

The distribution of the daily calorie intake is important in terms of the energy balance [25]. As was expected, female university students eat the largest amount of food at lunch. This applies to all subgroups of the SA in our study. These results are in line with the recommendation that lunch should cover $40-50 \%$ of the daily energy consumption [21]. However, it is essential to know the right time to eat lunch, because eating late will result in a poor diet. Our results suggest better eating habits in female students who regularly participate in SA with a frequency as low as once a week, although we found significant differences only between the female students who participated in sports 3 or more times a week and students who do not participate in SA or participate only irregularly. Our research also found a relatively high percentage of university students who consume the largest amount of food in the evening, especially in the group of inactive and irregularly active students. For the female students who participate in sports regularly once a week, this percentage was significantly lower. The reason may be the participation in SA in the evening, which forces the students to consume food well in advance of exercise or to consume less food towards the end of the day. This may be related to an awareness of the importance of a healthy lifestyle, which includes participation in SA and healthy eating habits [71]. On the other hand, reporting dinner as the most voluminous meal of the day in terms of the amount of food is not uncommon. The students who participated in a study at the Technical University in Prague stated that dinner was usually the only complete meal for which they had time [4].

In their senior year, the students' daily routine changes. This means that the students sleep later than before. Having the vigilance required in order to study and work hard until late at night requires consuming enough calories to withstand this onslaught, without craving extra food late at night. Only a small number of the female students involved in the research said that they did not eat dinner, which is a positive finding because the absence of dinner will cause the body to be without energy for a long time, as energy is not received during sleep. This can slow down the metabolism and increase the tendency to store body fat. In the past, restricting or avoiding food before bedtime had been proposed as a strategy for weight management, as well as an approach to improving health [72,73]. However, these results may not be consistent if the food selection is changed in order to prefer low-energy and/or macronutrient foods, up to $200 \mathrm{kcal}$ [74-77]. The results of our study showed that most female students who do not eat dinner participate in SA 3 or more times a week. However, the differences are insignificant, compared to other groups. The absence of dinner can be the result of a wrongly perceived lifestyle, which includes 
avoiding food intake before bed. An appropriate time for dinner seems to be $3-4 \mathrm{~h}$ before bedtime, which according to the study is followed by almost $60 \%$ of students. Dinner time within $3 \mathrm{~h}$ before bedtime significantly increases the risk of gastrointestinal problems and the incidence of stomach cancer (a 7.4-fold increased risk). Biologically, a short space of time between dinner and bedtime may reduce gastric motility and cause delayed gastric emptying, resulting in food retention in the stomach [78]. Conversely, with an earlier dinner, the nocturnal $\mathrm{pH}$ is higher than with a later dinner [79]. For this reason, an earlier dinner may be useful in conditions where low acidity in the stomach is desired. On the contrary, the benefits of an overnight nutrient supply can play a key role in sports nutrition, in the search for optimal body composition and improved performance [72]. Additionally, an intake of slow-release proteins in the correct composition shortly before bedtime can improve post-exercise regeneration [80].

In general, provided that the last meal of the day does not involve the largest amount of food and the frequency of eating 5 to 6 times a day is met, it is not advisable to eat the last meal more than $2 \mathrm{~h}$ before bedtime, but it is also not advisable to not dine at all [23]. It is ideal to combine dinner with mild SA. For example, a walk after dinner brings beneficial effects and leads to mental relaxation, which increases the ability of the immune system to fight certain diseases [78].

\section{Limitation of the Study}

This was a cross-sectional study, and no longitudinal data were available to review the differences considering the monitored lifestyle and health factors. Moreover, the questionnaire items were constructed for the research conducted at two universities in eastern Slovakia, which may distort the comparison with domestic and foreign research. Furthermore, this study considered neither socioeconomic, cultural, and religious factors nor the consumption of tobacco, alcohol, drugs, and medicines. In addition, the obtained data show a high level of subjectivity with respect to the methodology used.

\section{Conclusions}

The analysis of the research results conducted at two of the most significant universities in eastern Slovakia showed the predominance of a hypokinetic lifestyle of the monitored students. These results reflect the overall behaviour of university students in relation to physical activity, in Slovakia and abroad. Regular performance of sports activities with a frequency of sports at least once a week in the last six months was reported by just over a third of the students involved in the research. Most of the female students admitted irregular participation in sports activities. However, we confirmed that sports activity is an important factor related to diet in freshmen female university students. In particular, we found a significant relationship between participation in sports activity and the variables of daily eating frequency, distribution of the total daily food intake, and eating breakfast on a daily basis. We also found an insignificant relationship with dinner time before bedtime.

Author Contributions: Conceptualization, A.B. and K.Z.; methodology, A.B. and K.Z.; software, L.U.; formal analysis, A.B. and Z.K.; investigation, Z.K. and L.K.; resources, R.M. and Z.K.; writingoriginal draft preparation, A.B., R.M. and L.K.; writing-review and editing, K.Z. and Z.K.; visualization, A.B.; supervision, A.B.; project administration, K.Z., and Z.K.; funding acquisition, K.Z. All authors have read and agreed to the published version of the manuscript.

Funding: This study is not funded by any specific project grant.

Institutional Review Board Statement: The study was conducted according to the guidelines of the Declaration of Helsinki.

Informed Consent Statement: Informed consent was obtained from all probands involved in the study. 
Data Availability Statement: The raw data supporting the conclusions of this article will be made available by the authors, without undue reservation.

Conflicts of Interest: The authors declare no conflict of interest.

\section{References}

1. O'Dea, J.A. Gender, Ethnicity, Culture and Social Class Influences on Childhood Obesity among Australian Schoolchildren: Implications for Treatment, Prevention and Community Education. Health Soc. Care Community 2008, 16, 282-290. [CrossRef] [PubMed]

2. Kimáková, T. Monitoring of Selected Lifestyle Factors in University Students; Medical Faculty of Pavol Jozef Šafárik University, Institute of Public Health and Hygiene: Košice, Slovakia, 2018. (In Slovak)

3. Jurkovičová, J. Proper nutrition and healthy foods in the Prevention of Cardiovascular Disease. In Zdravý Životný Štýl: Cesta k Prevencii Ochorení Srdca a Ciev; AEPress: Bratislava, Slovakia, 2010; pp. 51-72. (In Slovak)

4. Valjent, Z.; Flemr, L. Selected aspects of the quality of life of technical university students. Kontakt 2010, 12, 414-424. [CrossRef]

5. Valjent, Z. Successful and unsuccessful university students in terms of selected indicators of the active living style. Kontakt 2011, 13, 216-229. [CrossRef]

6. Pengpid, S.; Peltzer, K. Prevalence and Associated Factors of Skipping Breakfast among University Students from 28 Countries: A Cross-Sectional Study. Int. J. Adolesc. Med. Health 2020. [CrossRef] [PubMed]

7. Pengpid, S.; Peltzer, K. Skipping Breakfast and Its Association with Health Risk Behaviour and Mental Health Among University Students in 28 Countries. Diabetes Metab. Syndr. Obes. 2020, 13, 2889-2897. [CrossRef] [PubMed]

8. Lowry, R.; Galuska, D.A.; Fulton, J.E.; Wechsler, H.; Kann, L.; Collins, J.L. Physical Activity, Food Choice, and Weight Management Goals and Practices among US College Students. Am. J. Prev. Med. 2000, 18, 18-27. [CrossRef]

9. Errisuriz, V.L.; Pasch, K.E.; Perry, C.L. Perceived Stress and Dietary Choices: The Moderating Role of Stress Management. Eat. Behav. 2016, 22, 211-216. [CrossRef] [PubMed]

10. Yahia, N.; Brown, C.A.; Rapley, M.; Chung, M. Level of Nutrition Knowledge and Its Association with Fat Consumption among College Students. BMC Public Health 2016, 16, 1047. [CrossRef]

11. El Ansari, W.; Stock, C.; Mikolajczyk, R.T. Relationships between Food Consumption and Living Arrangements among University Students in Four European Countries-A Cross-Sectional Study. Nutr. J. 2012, 11, 28. [CrossRef]

12. Korn, L.; Gonen, E.; Shaked, Y.; Golan, M. Health Perceptions, Self and Body Image, Physical Activity and Nutrition among Undergraduate Students in Israel. PLoS ONE 2013, 8, e58543. [CrossRef] [PubMed]

13. Sogari, G.; Velez-Argumedo, C.; Gómez, M.I.; Mora, C. College Students and Eating Habits: A Study Using an Ecological Model for Healthy Behavior. Nutrients 2018, 10, 1823. [CrossRef]

14. Abdelhafez, A.I.; Akhter, F.; Alsultan, A.A.; Jalal, S.M.; Ali, A. Dietary Practices and Barriers to Adherence to Healthy Eating among King Faisal University Students. Int. J. Environ. Res. Public Health 2020, 17, 8945. [CrossRef]

15. García-Meseguer, M.J.; Burriel, F.C.; García, C.V.; Serrano-Urrea, R. Adherence to Mediterranean Diet in a Spanish University Population. Appetite 2014, 78, 156-164. [CrossRef]

16. Cui, Y.; Zhang, W.; Gong, Q.; Chen, Y.; Chen, S.; Wu, Z. Frequency of Breakfast and Physical Fitness among Chinese College Students. Am. J. Health Behav. 2018, 42, 156-162. [CrossRef]

17. Ren, Z.; Cao, J.; Cheng, P.; Shi, D.; Cao, B.; Yang, G.; Liang, S.; Du, F.; Su, N.; Yu, M.; et al. Association between Breakfast Consumption and Depressive Symptoms among Chinese College Students: A Cross-Sectional and Prospective Cohort Study. Int. J. Environ. Res. Public Health 2020, 17, 1571. [CrossRef] [PubMed]

18. Bernasovská, K.; Kovářová, M.; Rimárová, K. Assessment of Lifestyle of Faculty of Medicine Students of UPJŠ in Košice. In Životné Podmienky a Zdravie: Zbornik Vedeckých Prác; Public Health Authority of SR: Bratislava, Slovakia, 2003; pp. 273-279. (In Slovak)

19. Bernasovská, K.; Kimáková, T.; Frank, K. Reflection of Changes in the Quality of Life of Faculty of Medicine Students. In Životné Podmienky a Zdravie: Zborník Vedeckých Prác; Public Health Authority of SR: Bratislava, Slovakia, 2009; pp. 119-122. (In Slovak)

20. Holéczyová, G.; Bernasovská, K.; Lovayová, V. Positive and Negative Factors in the Diet of University Students. In Životné Podmienky a Zdravie: Zborník Vedeckých Prác; Public Health Authority of SR: Bratislava, Slovakia, 2007; pp. 192-195. (In Slovak)

21. Zusková, K.; Buková, A.; Bakalár, P.; Brtková, M.; Kűchelová, Z.; Hančová, M. Overweight and Obesity in University Students. Selected Aspects of Lifestyle and Mental State, 1st ed.; Pavol Jozef Šafárik University-Šafárik Press: Košice, Slovakia, 2020; (In Slovak). [CrossRef]

22. Grygiel-Górniak, B.; Tomczak, A.; Krulikowska, N.; Przysławski, J.; Seraszek-Jaros, A.; Kaczmarek, E. Physical Activity, Nutritional Status, and Dietary Habits of Students of a Medical University. Sport Sci. Health 2016, 12, 261-267. [CrossRef] [PubMed]

23. Podstawski, R.; Choszcz, D.; Klimczak, J.; Kolankowska, E.; Zurek, P. Habits and Attitudes of First-Year Female Students at Warmia and Mazury University: A Call for Implementing Health Education Programme at Universities. Cent. Eur. J. Public Health 2014, 22, 229-238. [CrossRef]

24. Gazibara, T.; Tepavcevic, D.B.K.; Popovic, A.; Pekmezovic, T. Eating Habits and Body-Weights of Students of the University of Belgrade, Serbia: A Cross-Sectional Study. J. Health Popul. Nutr. 2013, 31, 330-333. [CrossRef] [PubMed]

25. Stea, T.H.; Torstveit, M.K. Association of Lifestyle Habits and Academic Achievement in Norwegian Adolescents: A CrossSectional Study. BMC Public Health 2014, 14, 829. [CrossRef] [PubMed] 
26. Ramírez-Vélez, R.; Triana-Reina, H.R.; Carrillo, H.A.; Ramos-Sepúlveda, J.A.; Rubio, F.; Poches-Franco, L.; Rincón-Párraga, D.; Meneses-Echávez, J.F.; Correa-Bautista, J.E. A Cross-Sectional Study of Colombian University Students' Self-Perceived Lifestyle. Springerplus 2015, 4, 289. [CrossRef] [PubMed]

27. Saygin, M.; Ongel, K.; Caliskan, S. Relation between Respiratory Function Tests and Life Habits of the University Students. Toxicol. Ind. Health 2015, 31, 396-402. [CrossRef]

28. Hussain, R.; Guppy, M.; Robertson, S.; Temple, E. Physical and Mental Health Perspectives of First Year Undergraduate Rural University Students. BMC Public Health 2013, 13, 848. [CrossRef]

29. Butler, S.M.; Black, D.R.; Blue, C.L.; Gretebeck, R.J. Change in Diet, Physical Activity, and Body Weight in Female College Freshman. Am. J. Health Behav. 2004, 28, 24-32. [CrossRef]

30. Hu, J.; Li, Z.; Li, S.; Li, H.; Wang, S.; Wang, S.; Xu, L.; Yang, D.; Ruan, T.; Li, H.; et al. Skipping Breakfast and Physical Fitness among School-Aged Adolescents. Clinics 2020, 75, e1599. [CrossRef]

31. Pliner, P.; Saunders, T. Vulnerability to Freshman Weight Gain as a Function of Dietary Restraint and Residence. Physiol. Behav. 2008, 93, 76-82. [CrossRef]

32. Vohs, K.D.; Heatherton, T.F.; Herrin, M. Disordered Eating and the Transition to College: A Prospective Study. Int. J. Eat. Disord. 2001, 29, 280-288. [CrossRef]

33. El Ansari, W.; Samara, A. Adherence to Recommended Dietary Guidelines and the Relationships with the Importance of Eating Healthy in Egyptian University Students. Int. J. Prev. Med. 2018, 9, 73. [CrossRef] [PubMed]

34. Brown, O.N.; O'Connor, L.E.; Savaiano, D. Mobile MyPlate: A Pilot Study Using Text Messaging to Provide Nutrition Education and Promote Better Dietary Choices in College Students. J. Am. Coll. Health 2014, 62, 320-327. [CrossRef] [PubMed]

35. Douglas, P.D.; Douglas, J.G. Nutrition Knowledge and Food Practices of High School Athletes. J. Am. Diet. Assoc. 1984, 84, 1198-1202.

36. Hendl, J.; Dobrý, L. Health Benefits of Physical Activity: Monitoring, Intervention, Evaluation; Karolinum: Prague, Czechia, 2011.

37. Von Bothmer, M.I.K.; Fridlund, B. Gender Differences in Health Habits and in Motivation for a Healthy Lifestyle among Swedish University Students. Nurs. Health Sci. 2005, 7, 107-118. [CrossRef] [PubMed]

38. Philipsen, S.C. Validation of a Newly Developed Eating Habits Questionnaire for New Zealand Women: A Thesis Presented for the Partial Fulfilment of the Requirements for the Degree of Master of Science in Human Nutrition at Massey University, Auckland, New Zealand. Master's Thesis, Massey University, Palmerston North, New Zealand, 2015.

39. Harriss, D.J.; Atkinson, G. Ethical Standards in Sport and Exercise Science Research. Int. J. Sports Med. 2013, 34, 1025-1028. [CrossRef] [PubMed]

40. Daniel, W.W. Biostatistics: A Foundation for Analysis in the Health Sciences; John Wiley \& Sons: New York, NY, USA, 1999.

41. Bergier, J.; Kapka-Skrzypczak, L.; Biliński, P.; Paprzycki, P.; Wojtyła, A. Physical Activity of Polish Adolescents and Young Adults According to IPAQ: A Population Based Study. Ann. Agric. Environ. Med. 2012, 19, 109-115. [PubMed]

42. Leslie, E.; Sparling, P.B.; Owen, N. University Campus Settings and the Promotion of Physical Activity in Young Adults: Lessons from Research in Australia and the USA. Health Educ. 2001, 101, 116-125. [CrossRef]

43. Pedišić, Ž.; Rakovac, M.; Bennie, J.; Jurakić, D.; Bauman, A.E. Levels and Correlates of Domain-Specific Physical Activity in University Students: Cross-Sectional Findings from Croatia. Kinesiology 2014, 46, 12-22.

44. Sigmundová, D.; Chmelík, F.; Sigmund, E.; Feltlová, D.; Frömel, K. Physical Activity in the Lifestyle of Czech University Students: Meeting Health Recommendations. Eur. J. Sport Sci. 2013, 13, 744-750. [CrossRef]

45. Varela-Mato, V.; Cancela, J.M.; Ayan, C.; Martín, V.; Molina, A. Lifestyle and Health among Spanish University Students: Differences by Gender and Academic Discipline. Int. J. Environ. Res. Public Health 2012, 9, 2728. [CrossRef]

46. Eurobarometer 2018. Sport and Physical Activity. Available online: https://europa.eu/eurobarometer/surveys/detail/2164 (accessed on 20 May 2021).

47. Helmer, S.M.; Krämer, A.; Mikolajczyk, R.T. Health-Related Locus of Control and Health Behaviour among University Students in North Rhine Westphalia, Germany. BMC Res. Notes 2012, 5, 703. [CrossRef]

48. Nykodým, J.; Zvonař, M.; Sebera, M. Physical Activity Of Masaryk University Students. Studia Sport. 2011, 5, 57-64. [CrossRef]

49. Radu, L.-E.; Făgăraş, S.-P.; Vanvu, G. Physical Activity Index of Female University Students. Procedia Soc. Behav. Sci. 2015, 191, 1763-1766. [CrossRef]

50. Kwan, M.Y.; Cairney, J.; Faulkner, G.E.; Pullenayegum, E.E. Physical Activity and Other Health-Risk Behaviors during the Transition into Early Adulthood: A Longitudinal Cohort Study. Am. J. Prev. Med. 2012, 42, 14-20. [CrossRef] [PubMed]

51. Gajdošík, J.; Baláš, J. The Interest In Physical Activities In Medical Students Of Charles University Prague. Studia Sport. 2012, 6, 62-69. [CrossRef]

52. Bíró, É.; Ádány, R.; Kósa, K. Mental Health and Behaviour of Students of Public Health and Their Correlation with Social Support: A Cross-Sectional Study. BMC Public Health 2011, 11, 871. [CrossRef]

53. Awadalla, N.J.; Aboelyazed, A.E.; Hassanein, M.A.; Khalil, S.N.; Aftab, R.; Gaballa, I.I.; Mahfouz, A.A. Assessment of Physical Inactivity and Perceived Barriers to Physical Activity among Health College Students, South-Western Saudi Arabia. East. Mediterr. Health J. 2014, 20, 596-604. [CrossRef] [PubMed]

54. Anand, T.; Tanwar, S.; Kumar, R.; Meena, G.S.; Ingle, G.K. Knowledge, Attitude, and Level of Physical Activity among Medical Undergraduate Students in Delhi. Indian J. Med. Sci. 2011, 65, 133-142. [CrossRef] 
55. Vajlent, Z. Why Does University Study Usually Mean an End to Sport Career? Acta Univ. Carol. Kinanthropol. 2009, 45, 115-129. (In Czech)

56. Bendíková, E. The Importance of Sports and Recreational Activities in the Lifestyle of University Students. In Šport a Zdravie $v$ Hodnotovej Orientácii Vysokoškolákov: Zborník z Vedeckej Konferencie; Comenius University in Bratislava: Bratislava, Slovakia, 2009; pp. 87-92. (In Slovak)

57. Buková, A.; Staško, I.; Gajdošová, B. Physical Activity of Pavol Jozef Šafrik University Students. In Telesná Výchova a Šport, Zdravie a Pohyb: Zbornik Referátov; Rokus s.r.o: Prešov, Slovakia, 2008; pp. 132-136. (In Slovak)

58. Hrcka, J.; Kovářová, M.; Beňačka, J. Physical Activity of Physiotherapy Students in Leisure Time and its Reflection on Selected Fitness and Health Characteristics; University of Ss. Cyril and Methodius in Trnava: Trnava, Slovakia, 2011. (In Slovak)

59. Bunc, V.; Skalská, M. Are Prerequisites for Physical Load in Persons with Overweight or Obesity Different than People with Normal Weight? Česká Kinantropologie 2011, 15, 55-63. (In Czech)

60. Koletzko, B.; Toschke, A.M. Meal Patterns and Frequencies: Do They Affect Body Weight in Children and Adolescents? Crit. Rev. Food Sci. Nutr. 2010, 50, 100-105. [CrossRef]

61. La Bounty, P.M.; Campbell, B.I.; Wilson, J.; Galvan, E.; Berardi, J.; Kleiner, S.M.; Kreider, R.B.; Stout, J.R.; Ziegenfuss, T.; Spano, M.; et al. International Society of Sports Nutrition Position Stand: Meal Frequency. J. Int. Soc. Sports Nutr. 2011, 8, 4. [CrossRef]

62. Schoenfeld, J.B.; Aragon, A.A.; Krieger, J.W. Effects of Meal Frequency on Weight Loss and Body Composition: A Meta-Analysis. Nutr. Rev. 2015, 73, 69-82. [CrossRef]

63. Feč, R.; Bukova, A.; Brtkova, M. Relationship between Diet and Body Fat Percentage in Female Undergraduates. Phys. Act. Rev. 2015, 3, 22-31. [CrossRef]

64. Buyken, A.E.; Cheng, G.; Günther, A.L.; Liese, A.D.; Remer, T.; Karaolis-Danckert, N. Relation of Dietary Glycemic Index, Glycemic Load, Added Sugar Intake, or Fiber Intake to the Development of Body Composition between Ages 2 and 7 y. Am. J. Clin. Nutr. 2008, 88, 755-762. [CrossRef] [PubMed]

65. Uher, I.; Küchelová, Z.; Cimboláková, I.; Pivovarník, J. Intermittent Fasting and Its Influence on Health. Phys. Act. Rev. 2016, 4, 184-191. [CrossRef]

66. Pilon, B. Eat Stop Eat; StrengthWorks International Publishing Inc.: WA, USA, 2013.

67. Zaccagni, L.; Barbieri, D.; Gualdi-Russo, E. Body Composition and Physical Activity in Italian University Students. J. Transl. Med. 2014, 12, 120. [CrossRef]

68. Baran, J.; Baran, R.; Czenczek-Lewandowska, E.; Leszczak, J.; Mazur, A.; Podgórska-Bednarz, J.; Pop, T.; Weres, A.; Wyszyńska, J. Physical Activity of Physiotherapy Students of the University of Rzeszów and Its Impact on the Subjects' Body Composition. Physiotherapy 2016, 102, e272-e273. [CrossRef]

69. Pendergast, F.J.; Livingstone, K.M.; Worsley, A.; McNaughton, S.A. Correlates of Meal Skipping in Young Adults: A Systematic Review. Int. J. Behav. Nutr. Phys. Act. 2016, 13, 125. [CrossRef] [PubMed]

70. Ghafari, M.; Doosti-Irani, A.; Amiri, M.; Cheraghi, Z. Prevalence of the Skipping Breakfast among the Iranian Students: A Review Article. Iran. J. Public Health 2017, 46, 882-889.

71. Yahia, N.; Wang, D.; Rapley, M.; Dey, R. Assessment of Weight Status, Dietary Habits and Beliefs, Physical Activity, and Nutritional Knowledge among University Students. Perspect. Public Health 2016, 136, 231-244. [CrossRef]

72. Kinsey, A.W.; Ormsbee, M.J. The Health Impact of Nighttime Eating: Old and New Perspectives. Nutrients 2015, 7, 2648. [CrossRef]

73. Cissé, Y.M.; Nelson, R.J. Consequences of Circadian Dysregulation on Metabolism. ChronoPhysiol. Ther. 2016, 6, 55-63. [CrossRef]

74. Kinsey, A.W.; Eddy, W.R.; Madzima, T.A.; Panton, L.B.; Arciero, P.J.; Kim, J.-S.; Ormsbee, M.J. Influence of Night-Time Protein and Carbohydrate Intake on Appetite and Cardiometabolic Risk in Sedentary Overweight and Obese Women. Br. J. Nutr. 2014, 112, 320-327. [CrossRef] [PubMed]

75. Ormsbee, M.J.; Kinsey, A.W.; Eddy, W.R.; Madzima, T.A. Corrigendum: The Influence of Nighttime Feeding of Carbohydrate or Protein Combined with Exercise Training on Appetite and Cardiometabolic Risk in Young Obese Women. Appl. Physiol. Nutr. Metab. 2019, 44, 228. [CrossRef] [PubMed]

76. Madzima, T.A.; Panton, L.B.; Fretti, S.K.; Kinsey, A.W.; Ormsbee, M.J. Night-Time Consumption of Protein or Carbohydrate Results in Increased Morning Resting Energy Expenditure in Active College-Aged Men. Br. J. Nutr. 2014, 111, 71-77. [CrossRef] [PubMed]

77. Leyh, S.M.; Willingham, B.D.; Baur, D.A.; Panton, L.B.; Ormsbee, M.J. Pre-Sleep Protein in Casein Supplement or Whole-Food Form Has No Impact on Resting Energy Expenditure or Hunger in Women. Br. J. Nutr. 2018, 120, 988-994. [CrossRef] [PubMed]

78. Xu, L.; Zhang, X.; Lu, J.; Dai, J.-X.; Lin, R.-Q.; Tian, F.-X.; Liang, B.; Guo, Y.-N.; Luo, H.-Y.; Li, N.; et al. The Effects of Dinner-to-Bed Time and Post-Dinner Walk on Gastric Cancer Across Different Age Groups. Medicine 2016, 95. [CrossRef]

79. Langella, C.; Naviglio, D.; Marino, M.; Calogero, A.; Gallo, M. New Food Approaches to Reduce and/or Eliminate Increased Gastric Acidity Related to Gastroesophageal Pathologies. Nutrition 2018, 54, 26-32. [CrossRef]

80. Kim, J. Pre-Sleep Casein Protein Ingestion: New Paradigm in Post-Exercise Recovery Nutrition. Phys. Act. Nutr. 2020, 24, 6-10. [CrossRef] 